\title{
Analyzing the Impacts of Wind Generation on Distribution System Performance
}

\author{
Anwar Ali Sahito ${ }^{1 *}$, Muhammad Azeem Arain' ${ }^{1}$ Irfan Ahmed Halepoto ${ }^{1}$, Mansoor Ahmed Soomro' \\ and Muhammad Juman Jumani² \\ 'Department of Electrical Engineering, Mehran UET, Jamshoro, Pakistan; anwar.sahito@faculty.muet.edu.pk \\ ${ }^{2}$ Hyderabad Electric Supply Company, Hyderabad, Pakistan
}

\begin{abstract}
Increasing wind power generation affects performance of existing power system in terms of power losses, voltage regulation and short circuit levels. Jhimpir wind generation having $49.5 \mathrm{MW}$ capacity is connected to $132 \mathrm{kV}$ network of Hyderabd Electric Supply Company (HESCO) to meet its energy demand. Distribution network of HESCO is modelled and simulated using Power system Simulator - Siemens Network Calculator (PSS SINCAL) as simulation platform. Simulation results are compared to observe impacts of wind integration to existing power system network. Simulation results indicate reduction of power losses from 15.26 to $14.79 \mathrm{MW}$ as a result of wind integration to existing HESCO network. Reduction in power losses is mainly caused by changed current flows in lines. Reduction in current also reduce line drops resulting in improved bus voltages. Short circuit level is slightly increased for all buses due to network modification. Increase in short circuit level is highest near the wind generation as Zorlu grid shows $13.02 \%$ increase. $66 \mathrm{kV}$ network shows small increase in short circuit level due to its long distance from wind generation facility. Use of real network data for this research work identifies possible protection issues alongwith the reduction in power losses and voltage drop. Each system network has separate network parameters and will have different response to any network change. Hence a simulation analysis is important to ensure maximum benefits from renewable energy sources and their integration with existing power system network
\end{abstract}

Keywords: Distribution System, Power Losses, Short Circuit Level, Voltage Regulation, Wind Generation

\section{Introduction}

Electricity consumers in Pakistan are facing long duration load shedding due to ever increasing generation-demand gap. High electricity cost makes consumers pay more despite being disturbed by planned load shedding and unplanned supply tripping ${ }^{1}$. Pakistan generates major portion of electricity through thermal and hydro generation. Oil prices, associated taxes and environmental concerns are some of the causes for not increasing thermal generation capacity. Increase in hydro generation is halted by national and international social and political issues regarding water. Pakistan has huge reserves of coal but cannot generate possible electricity because of international environmental concerns with quality of available $\mathrm{coal}^{2}$. Renewable energy is the only feasible option to achieve sustainable development. Increasing use of renewable energy sources was initiated by increasing oil prices and need for generation mix. Environmental aspects and world energy policies took over as major reasons behind renewable energy generation. Solar and wind generation are two renewable energy sources used extensively for power generation. Wind generation is most widely used generation source among renewable ${ }^{3}$. Pakistan is blessed with huge potential for wind and solar energy generation. Government is making policies to increase share of renewable energy generation. First large scale wind generation facility is located at Jhimpir near Karachi city. Turkish firm Zorlu started 49.5 MW wind generation, which is connected to Jhimpir grid station. It

${ }^{*}$ Author for correspondence 
supplies power consumers of Hyderabad Electric Supply Company (HESCO).

Power flow analysis is required to analyze steady state performance of any power system ${ }^{4}$. It determines bus voltages and power flowing through different system equipment like transformers, overhead and underground transmission and distribution lines. It is important to perform power flow analysis before any change in system is planned to ensure proper operation of the existing and proposed network ${ }^{5}$. For large power systems, computer simulation tools are available for load flow analysis. Power System Simulation - Siemens Network Calculator (PSS-SINCAL) is an excellent simulation software used for planning in distribution systems. Wind generation mainly depends upon available wind speed and its location is therefore dependent on good environmental and economic conditions. Hence it is important to analyze impacts of wind generation interconnection to existing power system. When large wind generation is connected to system, need of such system analysis become even more crucial. Wind generation integration to power system will change power flows resulting in possible changes in power losses, voltage regulation and short circuit levels.

Owing to increased trend for wind generation, various researchers are contributing to analyze different impacts and strategies to maximize its benefits. $\operatorname{In}^{6}$ a portion of power system in Germany was analyzed to observe impacts of wind generation addition. Study analyzed possible wind generation in the area and it was concluded that significant reduction in generation cost is achievable with large wind integration to selected system. Cost reduction analysis through wind generation was also performed by Lamount ${ }^{7}$. Sahito et al. ${ }^{5}$ analyzed impacts of wind generation on radial distribution feeder for voltage regulation, power losses and short circuit levels. They concluded that power system performance will be improved if proper size wind generation is connected at proper location in distribution system. Different conditions were developed for maximum energy cost reduction through wind generation integration to power system. Weng ${ }^{8}$ described new challenges of interconnected power system, and their planning to wind farm connected grid. From different wind turbines, wind power's uncertainty was calculated with fuzzy power flow calculations. Xie ${ }^{9}$ investigated the effects of wind mill integration with IEEE model system in. They concluded that wind mill will change the power flows and therefore it is necessary to select proper location and size for wind mill integration. In this research work, impacts of Jhimpir wind farm are analyzed on 132 and $66 \mathrm{kV}$ networks of HESCO using PSS SINCAL as simulation platform. Simulation results for network with and without Jhimpir wind farm are compared to analyze variation in bus voltages, line flows and short circuit level.

The rest of paper proceeds as follows: Section 2 of the paper describes wind generation concept, its operation and different types of generators used in wind farms. Section 3 gives details of the HESCO system and Jhimpir wind farm. Results are discussed in section 4. Finally, paper is concluded in section 5 .

\section{Wind Power}

Availability of sufficient wind velocity throughout the year is major consideration for site selection of wind generation. After selection of proper site, numbers of wind turbines are installed in group, which is termed as Wind Park or wind farm ${ }^{10}$. Direction of wind turbine is selected for maximum utilization of wind power. Typical wind turbine block diagram is shown in (Figure 1). Both synchronous and induction type of generators are used for wind generation system. If generator is directly connected to power grid, it is called direct grid connection. In this case generators need to run at constant speed, which is only possible if turbines rotate at constant speed. Hence mechanical system is required to maintain constant rotational speed. Power electronic interface is necessary for an indirect grid connection to control frequency of wind generated power for synchronization to grid network. Operation on variable speed of turbines is possible for indirect grid connection. Hence fixed speed, variable speed and semi variable speed are three categories of wind turbine generators. Generators used for generation of wind power include wound field synchronous generator, permanent magnet synchronous generator, squirrel cage induction generator and doubly fed induction generator.

Wind generation will have effects on power system depending on its location, size and type of generator used. High penetration of wind power will affect reliability of the power system. Wind power plants will affect line power flows in system network. As a result, bus voltages will have a change. These effects can either be positive or negative depending on the location and size of wind generation and power system network. During a fault restoration stage or contingency operation, wind generation will support system network by maintaining power flows 
and voltage support. Each wind power facility is equipped with reactive power control, which will help to improve voltage and power factor. Wind plants also perform a crucial role for stability, security and adequacy of the system. On the other hand, wind generation integration may need addition to distribution and transmission networks, distributed generation with small wind power facility being an exceptional condition. Large on-shore and off shore wind generation require large transmission network to be constructed for wind interconnection to power system network. It will increase overall cost of wind generation. Interconnection to national grid or neighboring countries will be necessary to manage large capacity wind plants. Efficiency of the existing system may be affected with wind integration as power flow changes may increase or decrease technical power losses in lines and distribution transformers. Suitable control schemes are required for large wind plants. Power exchange and generation scheduling will change drastically after wind integration to system. If this is not taken care of, results may include increased power losses, loss of synchronization and cascaded tripping of all generation facilities ${ }^{8}$.

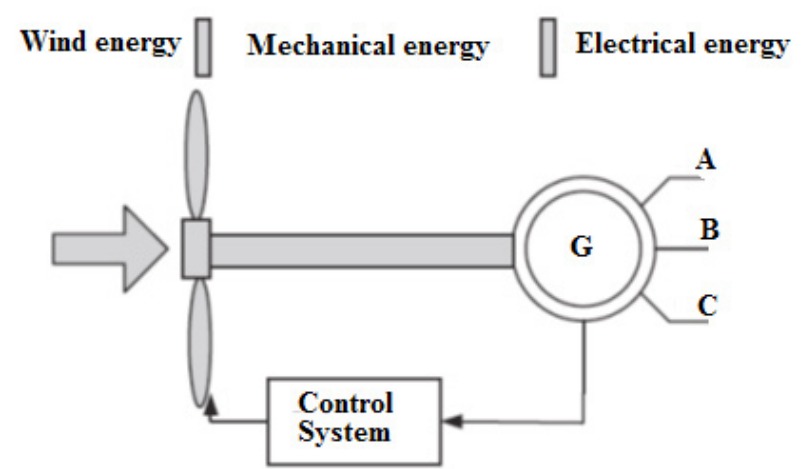

Figure 1. Energy conversion in wind turbine generator system.

\section{System Description}

HESCO is one of the ten distribution utilities created as a result of de regulation of Water and Power Development Authority (WAPDA) in Pakistan. It controls distribution system of in lower Sindh province. Its network starts at $132 \mathrm{kV}$ voltage level for secondary transmission system. Some of the areas still use $66 \mathrm{kV}$ lines and substations. Voltage is step down to $11 \mathrm{kV}$ and feeders carry power to different service areas where Pole Mounted Transformers (PMTs) step down voltage to utilization voltage. HESCO service area is covered by 70 substations; 50 of $132 \mathrm{kV}$ and 20 of $66 \mathrm{kV}$. Its secondary transmission network comprises of $2066.96 \mathrm{~km}$ lines of $132 \mathrm{kV}$ and $975.12 \mathrm{~km}$ of $66 \mathrm{kV}$. Like all distribution companies of Pakistan, HESCO is also facing problems of load shedding. Additionally, Transmission and Distribution losses in HESCO are more than $25 \%$. Jhimpir wind farm is located near Nooriabad area, which is one of the industrial hub of the Sindh province. 1250 acres of land has been reserved for wind generation in Jhimpir, district Thatta by Sindh provincial government. It consists of 33 wind turbines, each of 1.5 MW and more wind generation is expected at the same site. Zorlu Energy wind farm has been selected as $20 \mathrm{kV}$ for unit step up transformers, for collector cables and step up to $132 \mathrm{kV}$ at farm substation to connect HESCO grid.

\section{Result Discussions}

HESCO 132 and $66 \mathrm{kV}$ network is modelled and simulated using PSS-SINCAL software to observe technical impacts of Jhimpir wind farm. Simulation results for bus voltage, power losses and short circuit level are obtained through simulation of HESCO network with and without Jhimpir wind farm. (Table 1) compares bus voltages for some of the $132 \mathrm{kV}$ buses located near Jhimpir wind farm. All bus voltages have improved after Jhimpir integration to network. Bus voltages of all other buses have also improved slightly and are not shown in (Table 1) because of their distance from wind farm and radial nature of the selected network in the tail end areas. $66 \mathrm{kV}$ network is at the tail end side and has small effects of Jhimpir wind integration. Voltage comparison of some of the $66 \mathrm{kV}$ buses is given in (Table 2).

Table 1. Bus voltage comparison of $132 \mathrm{kV}$ HESCO network before and after Jhimpir wind integration

\begin{tabular}{|l|l|l|l|}
\hline \multirow{2}{*}{ Substation Bus } & \multicolumn{3}{l}{ Voltage $(\mathrm{kV})$} \\
\cline { 2 - 4 } & $\begin{array}{l}\text { Without } \\
\text { Jhimpir }\end{array}$ & $\begin{array}{l}\text { With } \\
\text { Jhimpir }\end{array}$ & Difference \\
\hline ZORLU & 140.47 & 141.56 & 1.09 \\
\hline FFC & 140.56 & 141.51 & 0.95 \\
\hline JHIRK & 139.55 & 140.28 & 0.73 \\
\hline JHIMPIR & 139.62 & 140.35 & 0.73 \\
\hline THATTA & 136.32 & 136.79 & 0.47 \\
\hline MIRPURSK & 134.61 & 135.08 & 0.48 \\
\hline SUJAWAL & 134.81 & 135.09 & 0.27 \\
\hline
\end{tabular}




\begin{tabular}{|l|l|l|l|}
\hline PHULLELI & 139.88 & 140.06 & 0.18 \\
\hline KOTRI SITE & 140.38 & 140.50 & 0.12 \\
\hline KOTRI GTPS & 140.45 & 140.56 & 0.11 \\
\hline LAKHRA & 139.39 & 139.53 & 0.14 \\
\hline JAMSHORO NEW & 139.84 & 139.99 & 0.15 \\
\hline JAMSHORO OLD & 139.91 & 140.02 & 0.11 \\
\hline NOORIABAD & 139.38 & 140.02 & 0.65 \\
\hline GULSHN SHBZ & 140.13 & 140.26 & 0.13 \\
\hline KALUKUHR & 138.91 & 139.56 & 0.65 \\
\hline QASIMABAD & 138.49 & 138.67 & 0.18 \\
\hline RAJPUTANA & 140.01 & 140.18 & 0.18 \\
\hline HYD-TMK-2 & 140.00 & 140.16 & 0.17 \\
\hline HYD-TMRD & 141.17 & 141.35 & 0.19 \\
\hline HYDNTPS & 139.95 & 140.11 & 0.16 \\
\hline KOHSAR & 140.40 & 140.55 & 0.15 \\
\hline ZEALPAKC & 139.93 & 140.09 & 0.16 \\
\hline LATIFABAD & 140.32 & 140.48 & 0.16 \\
\hline
\end{tabular}

Table 2. Bus voltage comparison of $66 \mathrm{kV}$ HESCO network before and after Jhimpir wind integration

\begin{tabular}{|l|l|l|l|}
\hline \multirow{2}{*}{ Substation Bus } & \multicolumn{3}{|l|}{ Voltage $(\mathrm{kV})$} \\
\cline { 2 - 4 } & $\begin{array}{l}\text { Without } \\
\text { Jhimpir }\end{array}$ & $\begin{array}{l}\text { With } \\
\text { Jhimpir }\end{array}$ & Difference \\
\hline T.G.ALI & 62.57 & 62.68 & 0.12 \\
\hline DIGRI & 60.36 & 60.49 & 0.14 \\
\hline BADIN & 65.63 & 65.74 & 0.11 \\
\hline TANDO BAGO & 63.58 & 63.71 & 0.13 \\
\hline KADHAN & 65.08 & 65.19 & 0.11 \\
\hline SAMARO & 69.71 & 69.87 & 0.16 \\
\hline UMARKOT & 66.68 & 66.81 & 0.13 \\
\hline CHACHRO & 66.31 & 66.44 & 0.13 \\
\hline PITHORO & 69.11 & 69.27 & 0.16 \\
\hline NABISRRD & 65.60 & 65.76 & 0.16 \\
\hline NOUKOT & 61.71 & 61.86 & 0.15 \\
\hline T-KALOI & 62.12 & 62.26 & 0.14 \\
\hline KALOI & 62.02 & 62.16 & 0.14 \\
\hline PANGIRO & 62.21 & 62.35 & 0.14 \\
\hline
\end{tabular}

Short circuit level analysis is important to identify possible requirement of circuit breaker capacities after any system modification. Short circuit level is defined as product of short circuit current and rated voltage at particular bus. (Table 3 ) shows short circuit level comparison

of some of the $132 \mathrm{kV}$ buses of HESCO network. Short circuit level comparison of some buses of $66 \mathrm{kV}$ network are given in (Table 4). It is quite clear that short circuit level has increased at all 132 and $66 \mathrm{kV}$ buses. Higher percentage increase in short circuit level is observed for buses near wind generation such as Zorlu, FFC and JHIMPIR. $66 \mathrm{kV}$ network being at the tail end has smaller percentage increase in short circuit level.

Table 3. Short circuit level comparison of $132 \mathrm{kV}$ HESCO network before and after Jhimpir wind integration

\begin{tabular}{|l|l|l|l|l|}
\hline \multirow{2}{*}{ Substation Bus } & \multicolumn{2}{|l|}{$\begin{array}{l}\text { Short circuit level } \\
\text { (MVA) }\end{array}$} & \multicolumn{2}{l|}{ Difference } \\
\cline { 2 - 5 } & $\begin{array}{l}\text { Without } \\
\text { Jhimpir }\end{array}$ & $\begin{array}{l}\text { With } \\
\text { Jhimpir }\end{array}$ & MVA & \%age \\
\hline ZORLU & 495.85 & 560.40 & 64.54 & $13.02 \%$ \\
\hline FFC & 494.09 & 556.99 & 62.90 & $12.73 \%$ \\
\hline JHIRK & 400.88 & 435.44 & 34.57 & $8.62 \%$ \\
\hline JHIMPIR & 522.81 & 583.07 & 60.26 & $11.53 \%$ \\
\hline THATTA & 426.05 & 459.68 & 33.63 & $7.89 \%$ \\
\hline MIRPURSK & 268.54 & 281.37 & 12.83 & $4.78 \%$ \\
\hline SUJAWAL & 390.98 & 416.38 & 25.41 & $6.50 \%$ \\
\hline PHULLELI & 585.36 & 628.68 & 43.32 & $7.40 \%$ \\
\hline KOTRI SITE & 599.10 & 647.31 & 48.21 & $8.05 \%$ \\
\hline KOTRI GTPS & 617.96 & 669.62 & 51.66 & $8.36 \%$ \\
\hline LAKHRA & 577.20 & 616.86 & 39.65 & $6.87 \%$ \\
\hline JAMSHORO NEW & 625.11 & 676.16 & 51.05 & $8.17 \%$ \\
\hline JAMSHORO OLD & 623.66 & 675.51 & 51.85 & $8.31 \%$ \\
\hline NOORIABAD & 506.79 & 560.36 & 53.58 & $10.57 \%$ \\
\hline GULSHN SHBZ & 600.57 & 648.91 & 48.34 & $8.05 \%$ \\
\hline KALUKUHR & 473.50 & 519.56 & 46.06 & $9.73 \%$ \\
\hline QASIMABAD & 573.31 & 615.13 & 41.82 & $7.29 \%$ \\
\hline RAJPUTANA & 593.46 & 638.28 & 44.81 & $7.55 \%$ \\
\hline HYD-TMK-2 & 572.05 & 613.80 & 41.75 & $7.30 \%$ \\
\hline HYD-TMRD & 570.09 & 613.08 & 42.99 & $7.54 \%$ \\
\hline HYDNTPS & 571.83 & 613.55 & 41.71 & $7.29 \%$ \\
\hline KOHSAR & 551.29 & 589.90 & 38.60 & $7.00 \%$ \\
\hline ZEALPAKC & 573.99 & 617.82 & 43.83 & $7.64 \%$ \\
\hline LATIFABAD & 551.29 & 589.90 & 38.60 & $7.00 \%$ \\
\hline
\end{tabular}

Table 5 shows comparison of active power flows in some of the $132 \mathrm{kV}$ lines near Jhimpir wind farm. Analysis shows change in active power flows of most of the lines. Some lines have increase in active power flows. These 
lines have change in power flows and power generated from wind farm is supplied through these lines. Some lines have reduction in active power flows as more power is supplied from other lines. Some lines have no change in power flows such as JHIMPIR-JHIRK and HYDNTPSZEALPAKC. These lines are at the end and connected in radial feeder, which is reason for no change in active power flows.

Table 4. Short circuit level comparison of $66 \mathrm{kV}$ HESCO network before and after Jhimpir wind integration

\begin{tabular}{|l|l|l|l|l|}
\hline \multirow{2}{*}{ Substation Bus } & \multicolumn{2}{l|}{ Voltage $(\mathrm{kV})$} & \multicolumn{2}{l|}{ Difference } \\
\cline { 2 - 5 } & $\begin{array}{l}\text { Without } \\
\text { Jhimpir }\end{array}$ & $\begin{array}{l}\text { With } \\
\text { Jhimpir }\end{array}$ & MVA & \%age \\
\hline T.G.ALI & 155.87 & 158.39 & 2.52 & $1.62 \%$ \\
\hline DIGRI & 138.80 & 140.77 & 1.97 & $1.42 \%$ \\
\hline BADIN & 137.22 & 139.22 & 2.00 & $1.46 \%$ \\
\hline TANDO BAGO & 129.38 & 131.12 & 1.74 & $1.34 \%$ \\
\hline KADHAN & 87.19 & 87.95 & 0.76 & $0.87 \%$ \\
\hline SAMARO & 207.43 & 212.35 & 4.92 & $2.37 \%$ \\
\hline UMARKOT & 159.23 & 162.11 & 2.88 & $1.81 \%$ \\
\hline CHACHRO & 69.12 & 69.60 & 0.48 & $0.69 \%$ \\
\hline PITHORO & 137.31 & 139.33 & 2.02 & $1.47 \%$ \\
\hline NABISRRD & 165.03 & 167.97 & 2.94 & $1.78 \%$ \\
\hline NOUKOT & 154.88 & 157.40 & 2.52 & $1.63 \%$ \\
\hline T-KALOI & 136.76 & 138.70 & 1.94 & $1.42 \%$ \\
\hline KALOI & 111.87 & 113.21 & 1.34 & $1.20 \%$ \\
\hline PANGIRO & 135.19 & 137.09 & 1.90 & $1.41 \%$ \\
\hline
\end{tabular}

Table 5. Line flow comparison of HESCO network before and after Jhimpir wind integration

\begin{tabular}{|l|l|l|l|}
\hline \multirow{2}{*}{ Line } & \multicolumn{3}{|l|}{ Active Power (MW) } \\
\cline { 2 - 4 } & $\begin{array}{l}\text { Without } \\
\text { Jhampir }\end{array}$ & $\begin{array}{l}\text { With } \\
\text { Jhampir }\end{array}$ & $\begin{array}{l}\text { Diffe } \\
\text {-rence }\end{array}$ \\
\hline ZORLU - JHIMPIR & 31.86 & 67.87 & 36.01 \\
\hline FFC - ZORLU & 15.57 & 31.99 & 16.42 \\
\hline FFC - NOORIABAD & 14.77 & 30.99 & 16.22 \\
\hline JHIMPIR - JHIRK & 1.51 & 1.51 & 0.00 \\
\hline JHIMPIR - THATTA & 41.01 & 48.81 & 7.79 \\
\hline JHIMPIR- NOORIABAD & 0.10 & 3.19 & 3.09 \\
\hline THATTA - SUJAWAL & 35.49 & 27.88 & -7.62 \\
\hline HALAROAD - PHULLELI & 57.44 & 58.56 & 1.12 \\
\hline HALAROAD - HYDNTPS & 22.22 & 23.51 & 1.29 \\
\hline
\end{tabular}

\begin{tabular}{|c|c|c|c|}
\hline $\begin{array}{l}\text { HALAROAD - } \\
\text { QASIMABAD }\end{array}$ & 0.67 & -4.12 & -4.79 \\
\hline $\begin{array}{l}\text { HALAROAD - } \\
\text { RAJPUTANA }\end{array}$ & 82.44 & 74.39 & -8.05 \\
\hline HALAROAD - MATIARI & 35.05 & 35.17 & 0.12 \\
\hline HYDNTPS - HYD-TMK & 68.54 & 66.10 & -2.44 \\
\hline HYD-TMK- T.M.KHAN & 49.50 & 45.86 & -3.65 \\
\hline HYD-TMRD - KOHSAR & 12.18 & 16.57 & 4.39 \\
\hline HYD-TMRD - LATIFABAD & 28.78 & 35.08 & 6.30 \\
\hline HYDNTPS - ZEALPAKC & 2.69 & 2.69 & 0.00 \\
\hline KOHSAR - KOTRI SITE & 22.38 & 17.99 & -4.39 \\
\hline KOTRI GTPS - LATIFABAD & 30.09 & 23.79 & -6.30 \\
\hline KOTRI GTPS - KOTRI SITE & 32.43 & 28.02 & -4.41 \\
\hline KOTRI GTPS - JHIMPIR & 11.00 & -13.87 & -24.87 \\
\hline $\begin{array}{l}\text { KOTRI GTPS - JAMSHORO } \\
\text { OLD }\end{array}$ & 20.09 & 12.08 & -8.01 \\
\hline $\begin{array}{l}\text { KOTRI GTPS - GULSHN } \\
\text { SHBZ - } 1\end{array}$ & 23.17 & 17.08 & -6.09 \\
\hline $\begin{array}{l}\text { JAMSHORO NEW - } \\
\text { QASIMABAD }\end{array}$ & 92.16 & 87.35 & -4.81 \\
\hline $\begin{array}{l}\text { JAMSHORO NEW - } \\
\text { RAJPUTANA }\end{array}$ & 92.91 & 84.79 & -8.12 \\
\hline $\begin{array}{l}\text { JAMSHORO NEW - } \\
\text { JAMSHORO OLD }\end{array}$ & -11.51 & 5.17 & 16.68 \\
\hline $\begin{array}{l}\text { NOORIABAD - } \\
\text { JAMSHORO OLD }\end{array}$ & -11.50 & 7.82 & 19.32 \\
\hline $\begin{array}{l}\text { JAMSHORO OLD - } \\
\text { GULSHN SHBZ }\end{array}$ & 11.61 & 5.53 & -6.08 \\
\hline $\begin{array}{l}\text { NOORIABAD - } \\
\text { KALUKUHR }\end{array}$ & 26.60 & 26.60 & 0.00 \\
\hline
\end{tabular}

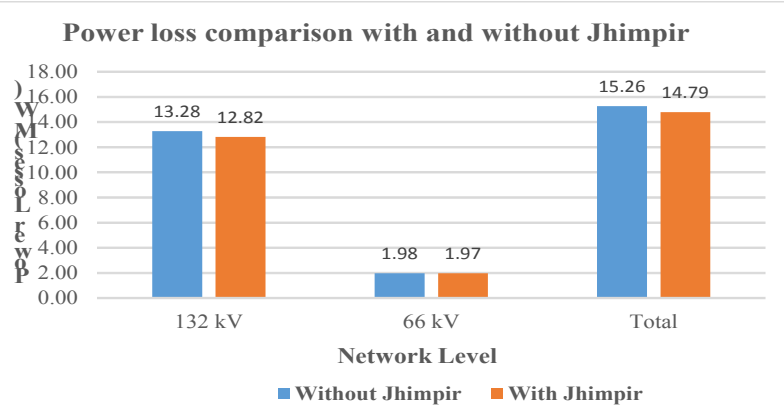

Figure 2. Power loss comparison of HESCO network with and without Jhimpir.

(Figure 2) graphically compares power losses in 132 and $66 \mathrm{kV}$ networks of HESCO. It is quite clear that power losses have reduced after Jhimpir wind farm integration. 
Power losses in $132 \mathrm{kV}$ network have reduced from 13.28 to $12.28 \mathrm{MW}$ indicating a reduction of $0.46 \mathrm{MW}$. As $66 \mathrm{kV}$ network is smaller than $132 \mathrm{kV}$ network, it has less power losses. Total power loss reduction in both networks is 0.47 MW (from 15.26 to $14.79 \mathrm{MW}$ ).

\section{Conclusion}

Wind generation is most widely form of renewable energy resources for power generation. Pakistan has huge electricity generation potential from wind. Jhimpir is first large scale wind generation connected to power system network. Nearly 50MW power is being supplied from wind farm and more is expected to be added soon. In this research work, impacts of Jhimpir wind farm on HESCO 132 and $66 \mathrm{kV}$ networks are analyzed for bus voltages, short circuit level, active power flows and power losses. Addition of Jhimpir wind power plants improves voltages for al buses. Increase in bus voltage varies with distance of the bus from wind generation and network configuration. Short circuit levels at all buses have slightly increased. Increase in short circuit levels near generators is higher as compared to others buses. For $66 \mathrm{kV}$ network small increase is observed in short circuit level due to its long distance from generation and radial nature of operation. Most of lines show change in active power flows depending on location and network configuration. Jhimpir wind generation results in reduction of power losses in HESCO network.

\section{Acknowledgements}

Authors are thankful to Mehran University of Engineering and Technology Jamshoro for providing necessary research facilities including simulation software.

\section{References}

1. Sahito AA, Halepoto IA, Tunio SM. Application of infrared thermography in power distribution system. Mehran University Research Journal of Engineering and Technology. 2014; 33(2):352-8.

2. Zuberi MJ, Ali SF. Greenhouse effect reduction by recovering energy from waste landfills in Pakistan. Renewable and Sustainable Energy Reviews. 2015; 44:117-131.

3. Siddique S, Wazir R. A review of the wind power developments in Pakistan. Renewable and Sustainable Energy Reviews. 2016; 57:351-61.

4. Halepoto IA, Uqaili UA, Chowdhry BS. Least square regression based integrated multi-parametric demand modeling for short term load forecasting. Mehran University Research Journal of Engineering and Technology. 2014; 33(2):215-26.

5. Sahito AA, Halepoto IA, Uqaili MA, Memon ZA, Larik AS, Mahar MA. Analyzing the impacts of distributed generation integration on distribution network: A corridor towards smart grid implementation in Pakistan. Wireless Pers. Communication, Springer. 2015; 85(2):545-63.

6. Olsina F, Roscher M, Larisson C, Garces F. Short-term optimal wind power generation capacity in liberalized electricity markets. Energy Policy. 2007; 35(2):1257-73.

7. Lamont AD. Assessing the long-term system value of intermittent electric generation technologies. Energy Economics. 2008; 30(3):1208-31.

8. Weng ZX, Shi LB, Xu Z, Yao LZ. Effects of wind power variability and intermittency on power flow. IEEE Power and Energy Society General Meeting, San Diego, CA, 2012 Jul 22-26; 2012. p. 1-7.

9. Xie L, Chiang HD, Li SH. Optimal power flow calculation of power system with wind farms. IEEE Power and Energy Society General Meeting, San Diego, 2011 Jul 24-29; 2011. p. 1-6.

10. Gupta N. A review on the inclusion of wind generation in power system studies. Renewable and Sustainable Energy Reviews. 2016; 59:530-43. 